To Maega $\mid$ Jurnal Pengabdian Masyarakat

Bulan-Tahun, Vol.4, No.1, hal, 55-62

$\operatorname{ISSN}(P): 2622-6332 ; \operatorname{ISSN}(E): 2622-6340$

http://www.ojs.unanda.ac.id/index.php/tomaega

\title{
Bentuk Kepedulian Antar Sesama Lewat Berkah Ramadhan di Tengah Wabah Covid-19
}

\author{
Mukhlis M ${ }^{1,}{ }^{*}$, Kasmawati ${ }^{2}$, Raznilawati Z ${ }^{3}$ \\ ${ }^{1}$ Program Studi Teknik Mesin Universitas Khairun \\ 2 Program Studi Sastra Jepang Universitas Hasanuddin \\ 3 Program Studi Manajemen Universitas Andi Djemma \\ *Correspondent Email: mukhlis@unkhair.ac.id
}

Article History:

Received: 5-11-2020; Received in Revised: 16-11-2020; Accepted: 7-12-2020

DOI: http://dx.doi.org/10.35914/tomaega.v4i1.485

\begin{abstract}
Abstrak
Tujuan pengabdian ini sebagai bentuk kepedulian antar sesama dalam membantu pemerintah mengurangi beban rakyat di tengah wabah covid-19 dengan pemberlakuan Pembatasan Sosial Berskala Besar (PSBB) di Makassar khususnya pada lingkungan perumahan Pesona Pelangi Residence. Kegiatan ini dilakukan dengan metode pengumpulan dana dari warga Pesona Pelangi Residence berupa paket sembako dengan konversi dana minimal Rp.50.000. Kegiatan ini dimulai pada minggu pertama hingga minggu ke tiga bulan Ramadhan. Adapun hasil pengumpulan dana di peroleh 250 paket sembako dan sembako lainya. Penerima sembako terdiri dari Warga PPR, Warga pinggiran sungai BTP Blok AF, warga lingkungan Biringjene, Satpam PPR, Tukang PPR, Petugas sampah PPR, Ojek Online, Ojek pangkalan, Pemulung, dan Pengemis.
\end{abstract}

Kata Kunci: covid-19, sembako, berkah Ramadhan.

\begin{abstract}
The purpose of this service is a form of concern among others in helping the government reduce the burden on the people in the midst of the Covid-19 outbreak by implementing Large-Scale Social Restrictions (PSBB) in Makassar, especially in the housing area of Pesona Pelangi Residence. This activity is carried out by collecting funds from the residents of Pesona Pelangi Residence in the form of food packages with a minimum conversion of IDR 50,000. This activity starts in the first week to the third week of Ramadan. As for the results of fundraising, 250 packages of groceries and other basic necessities were obtained. The food recipients consist of PPR residents, BTP Block AF riverbank residents, Biringjene neighborhood residents, PPR security guards, PPR workers, PPR garbage officers, online ojek, base ojek, scavengers, and beggars.
\end{abstract}

Keywords: Covid-19, groceries, blessings Ramadhan. 


\section{Pendahuluan}

Covid-19 berdampak pada perekonomian Indonesia saat ini, dimana terjadi sulitnya mencari lapangan pekerjaan, sulit memenuhi kebutuhan sehari-hari, dan masih banyak lagi kesulitan yang diterima bukan hanya dari sektor perekonimian akan tetapi sektor lain juga merasakan dampak dari Covid-19 (Nasution, Erlina, \& Muda, 2020).

Pandemi corona virus 2019 (Covid-19) membuat masyarakat menjadi stres (Afifah, 2020). Kecemasan dan ketakutan tentang penyakit tersebut menyebabkan pengaruh yang kuat pada masyarakat. Perubahan perilaku yang di sarankan pemerintah seperti jaga jarak (Pinjungwat, 2020), dapat membuat orang merasa terisolasi dapat meningkatkan kecemasan dan. stres Namun, tindakan ini diperlukan untuk mengurangi penyebaran COVID-19 (Jati, 2020).

Pandemi Covid-19 ini seharusnya tidak membuat kita jadi membatasi jarak pada kepedulian sosial terhadap sekitar (Very, 2020). Ibadah puasa di bulan Ramadan dapat menjadi sarana melatih diri untuk mengendalikan hawa nafsu yang juga bertujuan memupuk kepedulian bagi sesama umat manusia. Dampak Pandemi Covid-19 ini masyarakat justru memicu semakin meningkat kepedulian sosialnya. Ini terbukti adanya fenomena bagi-bagi makanan di jalan (Dwianto, 2020). Kepedulian terhadap orang lain sangat dibutuhkan selama masa pandemi. Walau ada kesulitan, kita bisa melakukan sesuatu untuk menolong sesama (mediaindonesia, 2020).

Spontanitas bantuan dari masyarakat muncul selama pandemi Covid-19 dilakukan tanpa harus diimbau oleh pemerintah atau pihak mana pun. Karena hal ini sejatinya merupakan budaya masyarakat bangsa Indonesia untuk bergotong royong membantu antarsesama manusia. Pandemi Covid-19 menyebabkan masyarakat ekonomi lemah yang sebenarnya paling berat permasalahannya. Karena orang yang biasanya bekerja dengan rutin, sekarang menjadi tidak bisa bekerja karena adanya bencana wabah ini. Apalagi kalau mereka adalah para pekerja di sektor informal dengan upah harian. Bisa dibayangkan orang yang biasanya kerja dengan upah harian untuk kehidupannya lalu tiba-tiba tidak kerja, tentu dampaknya sangat luar biasa berat buat mereka. Tetapi yang penting sesungguhnya sepanjang situasi negara ini aman, damai dan tidak ada kriminalitas yang terlalu parah masyarakat masih bisa melalui itu semua karena solidaritas kemanusiaan untuk membantu antar sesama muncul.

Hal ini juga terjadi lantaran dalam bulan Ramadan, puasa yang dilakukannya paling tidak juga membuat orang nafsunya menjadi tidak berkobar-kobar sehingga dapat meminimalkan terjadinya hal-hal yang bisa merugikan semuanya seperti kerusuhan. Oleh karena itu, salah satu bentuk kepedulian adalah pembagian paket sembako Ramadhan, meski ini sifatnya hanya sementara namun rasa kepedulian mampu membangkitkan semangat kebersamaan. Selain itu selama bulan puasa ini secara swadaya masyarakat biasanya mengirimkan makanan untuk buka dan sahur 
di masjid lalu juga untuk masyarakat kurang mampu disekitarnya. Jadi insya Allah puasa itu meredakan potensi konflik di masyarakat.

Selain ibadah puasa, kewajiban melakukan zakat saat Ramadan berlangsung. Apalagi zakat fitrah itu biasanya terserap untuk masyarakat kurang mampu di sekitar. Karena kejadian pandemi Covid-19 ini jumlah yang bisa bayar zakat bisa jadi berkurang (Irham, 2020). Seperti zakat ke lembaga nasional Baznas dan lainnya itu mungkin berkurang sekarang ini karena orang biasanya zakat mungkin juga terkena dampak dari pandemi covid ini. Dengan kondisi masyarakat seperti itu, dapat memaklumi adanya kekurangan dari pemerintah dalam penanganan wabah ini karena memang hal ini cukup berat. Sehingga kami dan warga perumahan Pesona Pelangi Residence melalui pengurus masjid Al- hakim membentuk panitia berkah Ramadhan untuk membantu sesama di tengah wabah Covid-19.

\section{Metode}

Metode yang digunakan dalam kegiatan ini yaitu pengumpulan dana dari warga perumahan Pesona Pelangi Residence dengan konversi Rp.50.000/paket sembako. Tahapan dalam kegiatan ini sebagai berikut:

1. Perencanaan dan Persiapan

Tim pelaksana berkoordinasi dengan pengurus Masjid Al- Hakim Perumahan Pesona Pelangi Residence mengenai berapa besaran dana, cara pembagian paket sembako, penentuan penerima paket sembako.

2. Sosialisasi Kegiatan

Sosialisasi dilaksanakan untuk memberikan pengumuman kepada warga Pesona Pelangi Residence mengenai kegiatan Paket Sembako Ramadhan.

3. Pembagian Paket Sembako Ramadhan

Pembagian Paket sembako Ramadhan dilakukan dengan 5 tahap. Tahap 1 di bagikan ke warga didalam perumahan, tahap 2 di bagikan ke warga sekitar, tahap 3 dibagikan ke warga pinggiran sungai bumi tamalanre indah, tahap 4 dibagikan ke pemulung, dan tahap 5 di bagikan ke warga di belakan perumahan

Adapun contoh paket seperti pada Gambar 1 berikut:

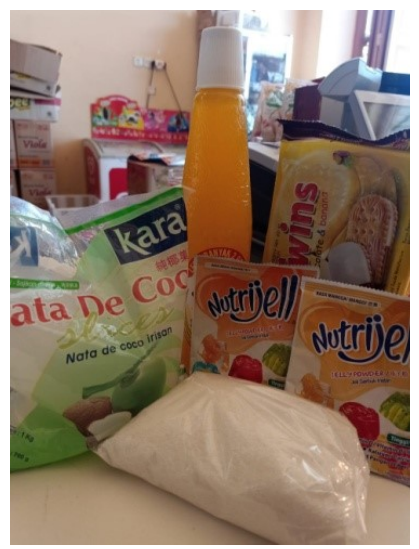

Gambar 1. Contoh Sembako yang di Kemas dalam Paket 


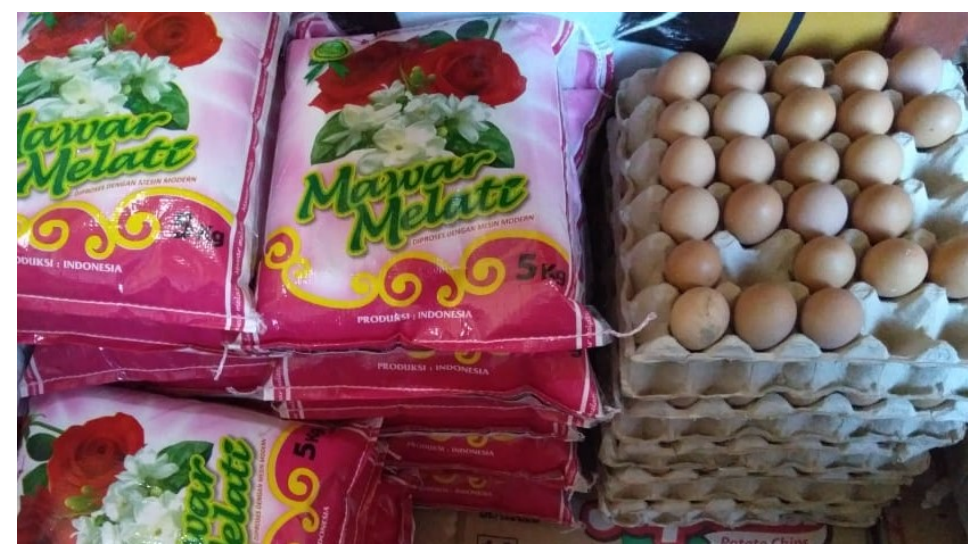

Gambar 2. Contoh paket besar dan telur

\section{Hasil dan Pembahasan}

Adapun hasil kegiatan, menunjukkan bahwa dengan pengumpulan dana dari warga Pesona Pelangi Residence tersebut dihasilkan 250 paket sembako berkah Ramadhan yang dibagikan kepada para penerima sembako melalui 5 tahap. Dari kelima tahap tersebut dapat memberikan manfaat yang bisa membantu orang lain yang hidupm berdampingan dengan kita, adapaun tahapan tersebut, sebagai berikut:

Tabel 1. Rincian tahapan pembagian sembako

\begin{tabular}{c} 
Tahap $1=56$ paket \\
Tahap $2=43$ paket \\
\hline Tahap $3=45$ paket \\
\hline Tahap $4=84$ paket \\
\hline Tahap $5=23$ paket
\end{tabular}

Adapun kami menerima paket tambahan yang bukan berupa uang tunai berupa paket sembako berupa telur, kurma,beras, dan paket sembako yang seperti pada tabel berikut:

Tabel 2. Rician Paket Tambahan dari Warga

\begin{aligned} & \hline - Paket kurma 2 dos \\ & \hline- Paket beras 1 karung + mie \\ & \hline- Paket telur \\ & \hline- 10 kg beras \\ & \hline 1 Paket sembako \\ & \hline\end{aligned}

Penyaluran paket sembako ke beberapa tempat sebagaimana dijelaskan pada tabel berikut. 
Tabel 3. Penerima Paket di Sekitar Wilayah Perumahan Pesona Pelangi Residence

\begin{tabular}{cl}
\hline NO & Penerima Bantuan Paket Sembako Ramadhan \\
\hline $\mathbf{1}$ & Warga PPR \\
\hline $\mathbf{2}$ & Warga pinggiran sungai BTP Blok AF \\
\hline $\mathbf{3}$ & warga lingkungan Biringjene \\
\hline $\mathbf{4}$ & Satpam PPR \\
\hline $\mathbf{5}$ & Buruh bangunan \\
\hline $\mathbf{6}$ & Petugas sampah PPR \\
\hline $\mathbf{7}$ & Ojek Online \\
\hline $\mathbf{8}$ & Ojek pangkalan \\
\hline $\mathbf{1 0}$ & Pemulung \\
\hline
\end{tabular}

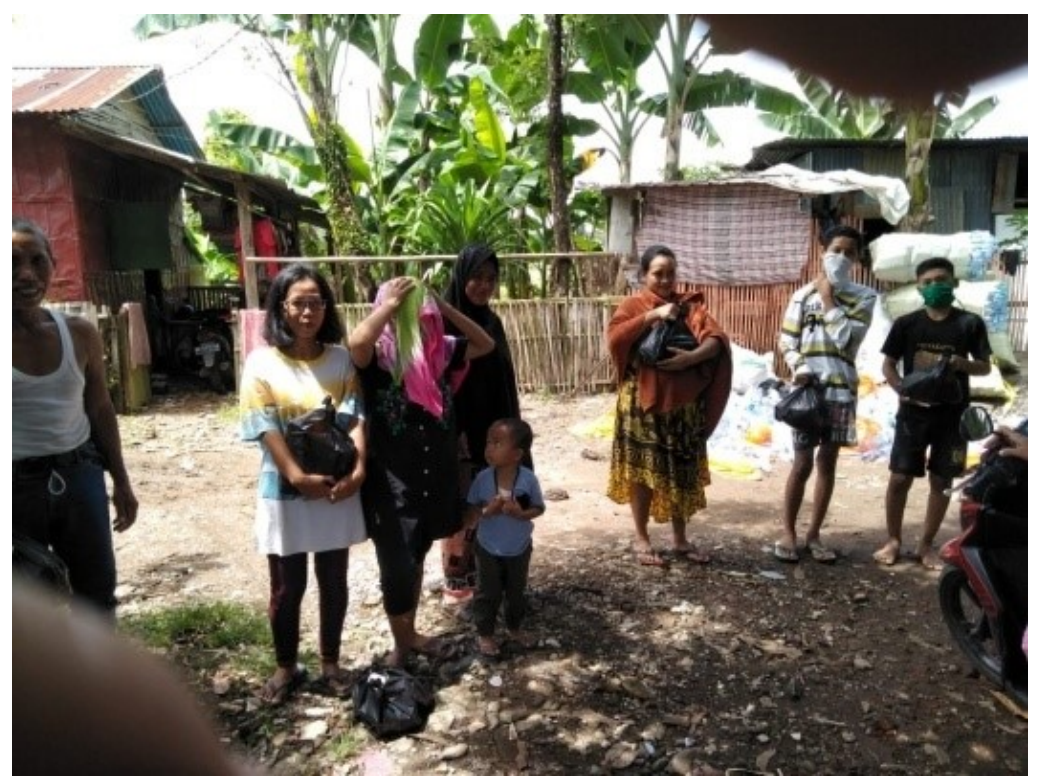

Gambar 3. Proses pembagian sembako di pinggir sungai BTP Blok AF dan pemulung Makassar

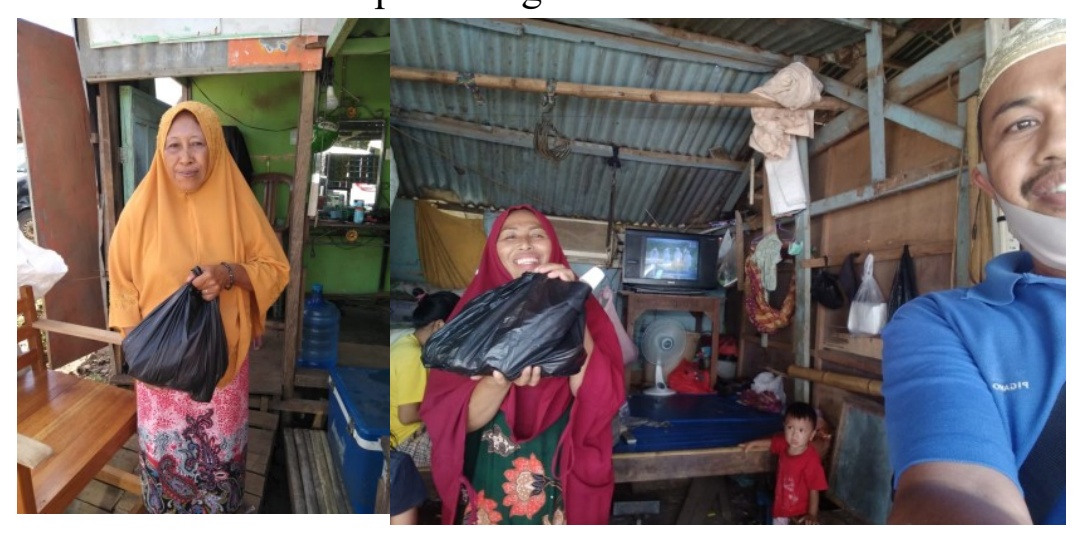


Gambar 4. Proses Pembagian Sembako Warga Kurang Mampu Sekitar Perumahan

Penerima paket di lingkungan Biringjene (Rumah penduduk di belakan Perumahan Pesona Pelangi Residence).

Tabel 4. Daftar nama Penerima Bantuan Sembako Ramadhan Dikampung Belakang Perumahan

\begin{tabular}{|c|c|c|c|}
\hline No & \multicolumn{3}{|c|}{ Warga Lingkungan Biringjene } \\
\hline 1 & Rt C & Rt B & Rt A \\
\hline 2 & Dg Rabaiyah & Dg Tati & Buba \\
\hline 3 & Dg Sitti & Dg Basse & Dg Jale \\
\hline 4 & Dg Kalu & Dg Jumasia & Dg Ati \\
\hline 5 & Dg Rohani & Dg Sania & Dg Mina Caya \\
\hline 6 & Culli & Dg Nurdin & Mica \\
\hline 7 & Syarifa Bur & Dg Saenang & Dg Mintang \\
\hline 8 & Nuntung & Dg Lu'mu & Dg Rukia \\
\hline 9 & Dg Raba & Nia & Dg Jaenong \\
\hline 10 & Dg Muna & Dg Pajja & Sittiara \\
\hline 11 & Dg Lapiang & Maria & Sonna \\
\hline 12 & Hasni Muhtar & Candi & Dg Rowa \\
\hline 13 & Dg Maddo & Dg Mansio & Agus \\
\hline 14 & Dg Nia Sabang & Dg Bani & Yasse \\
\hline 15 & Dg Rimang Sahabu & Dg Muri & Dg Sudding \\
\hline 16 & Dg Tobo & Dg Sauri & Sanudding Wati \\
\hline 17 & Dg Hania & & Kamisa Tono \\
\hline 18 & Mari & & Nurdin Sania \\
\hline 19 & Nurhayati & & Alimuddin Lija \\
\hline 20 & Dg Rasi & & \\
\hline 21 & Irwan & & \\
\hline 22 & Dg Sugi & & \\
\hline
\end{tabular}

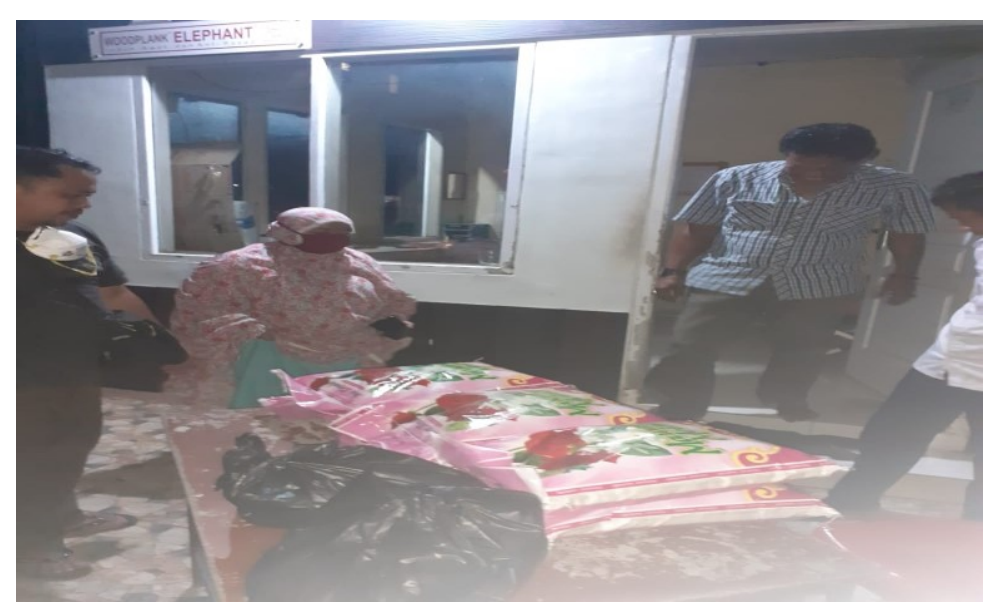




\section{Gambar 5. Proses Pembagian Sembako Kepada Satpam Perumahan Pesona} Pelangi Residence

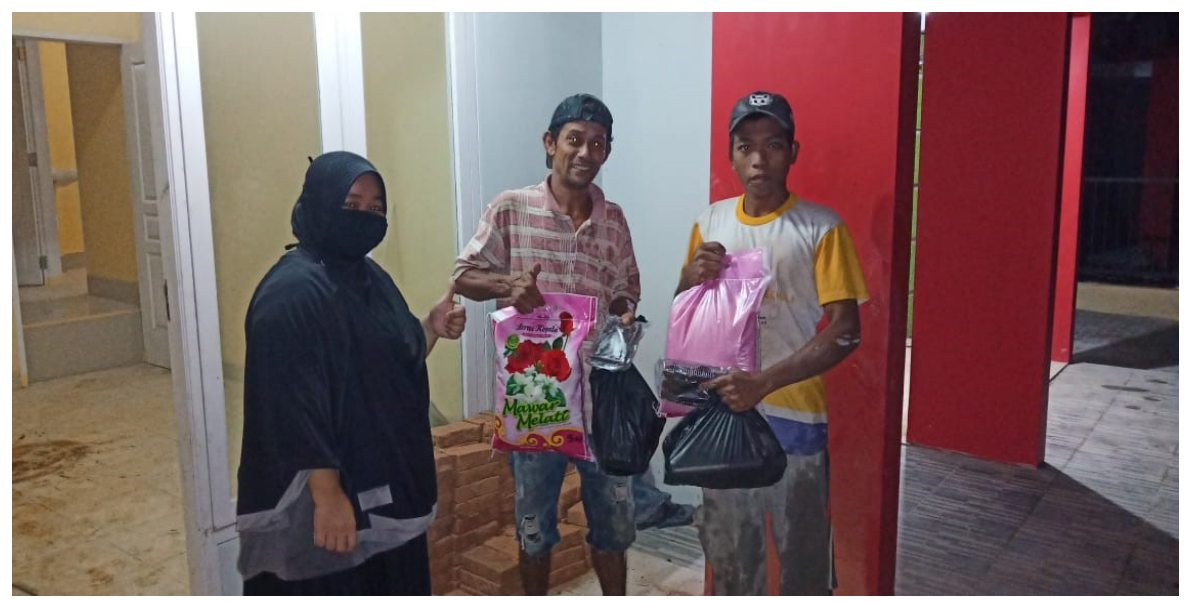

Gambar 6. Proses pembagian sembako kepada buruh bangunan di perumahan Pesona Pelangi Residence

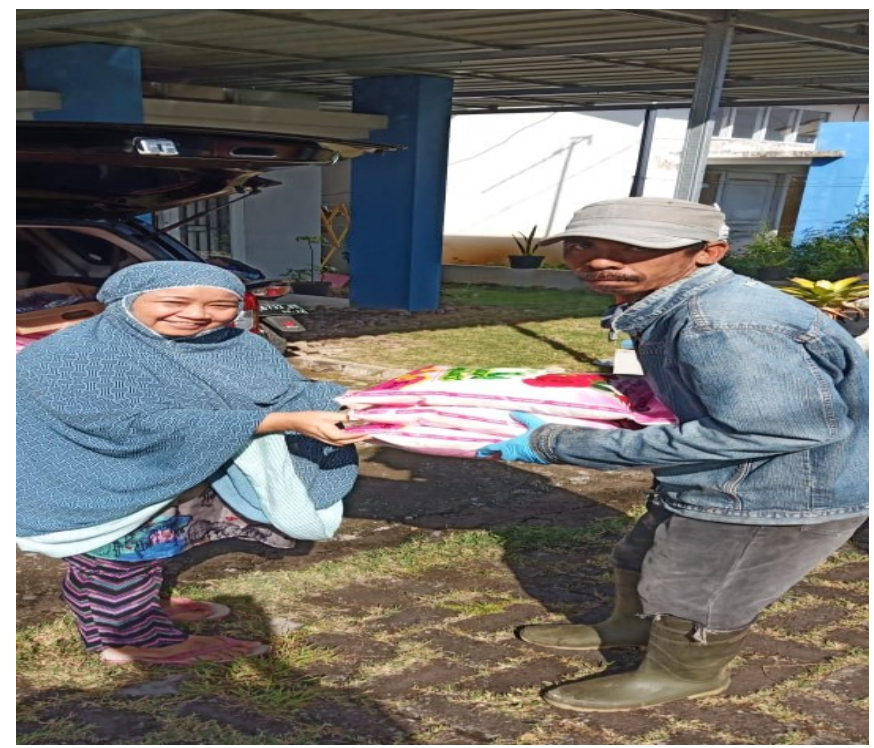

Gambar 7. Proses Pembagian Sembako Petugas Sampah

Adapun tanggapan masyarakat yakni dengan adanya kegiatan ini dapat membantu warga sekitar, karena dimasa pendemi penghasilan mereka menurun, banyak dari mereka yang di berhentikan dari tempat kerja, aktivitas ekonomi melambat, dan sulit beraktifitas karena di batasi oleh pemerintah lewat pembatasan sosial berskala besar. Masyarakat penerima bantuan juga memberi saran bahwa kedepannya akan lebih baik lagi sehingga lebih banyak lagi yang terbantukan lewat program semacam ini, terlebih lagi dimasa pendemi kesuliatan memenuhi kebutuhan pokok, maka masyarakat yang meneriman bantuan ini merasa perlu berterima kasih atas kontribusinya. 


\section{Kesimpulan}

Adapun kesimpulan dari pelaksanaan kegiatan pengabdian masyarakat yaitu (1) Pengumpulan dana dari warga Pesona Pelangi Residence berupa paket sembako di peroleh 250 paket sembako; (2) Penerima sembako terdiri dari: Warga PPR, Warga pinggiran sungai BTP Blok AF, warga lingkungan Biringjene, Satpam PPR, Tukang PPR, Petugas sampah PPR, Ojek Online, Ojek pangkalan, Pemulung, Pengemis; (3) Kepedulian warga Pesona Pelangi Residence dalam kegiaatan berkah Ramadhan di tengah pendemi semakin baik. Adapun saran yang diberikan yaitu (1) Diharapkan kegiatan pengabdian ini dapat berlanjut tidak hanya dimasa pendemi covid-19; (2) Diharapkan agar kegiatan ini senantiasa diberi kemudahan dan terpelihara, sehingga partisipasi warga semakin banyak di kegiatan berikutnya.

\section{Daftar Pustaka}

Dwianto. (2020). Pakar Gizi Komunitas Komentari Fenomena Bagi-bagi Makanan Saat Pandemi. Retrieved October 21, 2020, from https://health.detik.com/berita-detikhealth/d-4995991/pakar-gizi-komunitaskomentari-fenomena-bagi-bagi-makanan-saat-pandemi

Aning, J. (2020). 9 Upaya Pencegahan Penularan Corona Covid-19. Retrieved October 21, 2020, from https://www.liputan6.com/otomotif/read/4212220/9upaya-pencegahan-penularan-corona-covid-19

Pinjungwat. (2020). Melakukan Jarak Sosial untuk Mencegah Penyebaran Virus Corona. Retrieved October 21, 2020, from https://www.fimela.com/lifestylerelationship/read/4205247/melakukan-jarak-sosial-untuk-mencegahpenyebaran-virus-corona

Afifah. (2020). Bagaimana Dampak Stres Pandemi Corona pada Kesehatan Mental dan Fisik? Retrieved October 21, 2020, from https://health.kompas.com/read/2020/05/10/190700368/bagaimana-dampakstres-pandemi-corona-pada-kesehatan-mental-dan-fisik-?page $=$ all.

Mediaindonesia.(2020). Retrieved October 21, 2020, from https://mediaindonesia.com/read/detail/345142-masa-pandemi-kesempatanuntuk-tingkatkan-kepedulian-masyarakat

Irham. (2020). Virus corona dan zakat "online": Pandemi Covid-19 ubah tata cara membayar dan menyalurkan zakat, "Apakah sah bayar zakat tanpa bersalaman?" Retrieved October 21, 2020, from https://www.bbc.com/indonesia/indonesia-52380332

Nasution. (2020). Dampak Pandemi COVID-19 terhadap Perekonomian Indonesia. Jurnal Benefita, 5(2), 212. https://doi.org/10.22216/jbe.v5i2.5313

Very. (2020). Pandemi virus corona atau covid-19 ini tidak seharusnya membuat kita jadi membatasi jarak pada kepedulian sosial terhadap sekitar. Retrieved October 21, 2020, from https://indonews.id/artikel/29305/Kepedulian-SosialMasyarakat-Membatu-Meningkat-Saat-Pandemi-COVID-19/ 